\title{
Violência policial e juventude em Campinas: processos de deslegitimação do jovem como
} sujeito de direitos.

\section{Marina de O. Ribeiro.*, Luana B. da Silva, Frederico N. R. de Almeida.}

\section{Resumo}

Ao analisar dados de procedimentos administrativos de apuração de violência contra adolescentes por agentes de segurança pública, disponibilizados pela Promotoria de Justiça Cível de Campinas, do Ministério Público do Estado de São Paulo, foi possível comprovar que a violência policial em Campinas segue a mesma do padrão nacional, ou seja, os princiais alvos continuam sendo a juventude, negra, periférica e os protagonistas das agressões são majoritariamente polícias militares. Partindo da análise destes 71 procedimentos administrativos, a pesquisa se direcionou ao estudo da relação entre a juventude e polícia, ressaltando a longa historicidade da brutalidade policial contra a juventude marginalizada, a qual foi enquadrada como um transtorno para o desenvolvimento da nação a partir do século XIX, e, consequentemente, tratada como um problema que precisaria ser combatido e até eliminado. Neste momento, a violência policial foi concebida como um mecanismo pedagógico para a não inserção do jovem no "mundo do crime", lógica esta que legitimou e retroalimentou a brutalidade policial. Ademais, analisei como os policiais dificultam a implementação de uma resposabilização jurídica alternativa aos jovens, prevista pelo Estatuto da Criança e do Adolescente, no momento em que são a porta de entrada ao sistema de justiça e os próprios os principais infratores destes direitos.

\section{Palavras-chave: \\ Juventude, Polícias, Violência.}

\section{Introdução}

A juventude negra periférica é sabidamente o grupo preferencial da violência policial, deste modo, é possível constatar diferentes experiências de ser jovem, as quais são diversificadas a partir de marcadores sociais de raça, classe e gênero. Deste modo, no mundo social não há uma juventude no singular, mas sim "juventudes".

A partir da análise dos dados obtidos de como se configura a violência policial em Campinas, buscamos compreender como as juventudes campineiras são afetadas por este fenômeno em diferentes idades, territorialidades, classe, raça e gênero.

As juventudes, legalmente definida por pessoas de 15 a 29 anos, foram reconhecidas juridicamente como sujeitos de direitos a partir do Estatuto da Criança e do Adolescente, contudo, estes direitos apresentam muitas dificuldades de implementação, principalmente devido a conduta policial.

\section{Resultados e Discussão}

Os dados obtidos dos procedimentos analisados nos possibilitaram constatar que entre os jovens $95,28 \%$ foram registrados como homens, $48,11 \%$ registrados como pardos e $36,79 \%$ detém o ensino fundamental completo. Já em relação aos atos infracionais nos quais foram acusados, $73,24 \%$ são crimes contra o patrimônio. Já sobre as forças de segurança, $80,28 \%$ dos condutores são policiais militares e $77,46 \%$ das testemunhas dos casos também são policiais militares. Dentre os condutores, $28,16 \%$ são brancos e $64,78 \%$ não foram informados a cútis nos registros.

Os motivos e circunstâncias da abordagem são $77,46 \%$ patrulhamento de rotina, 53,52\% tentativa de fuga e $39,44 \%$ apuração de atitude suspeita.

Os meios de violência sofrida pelos adolescentes são $84,51 \%$ tapas, socos e chutes e $33,80 \%$ ofensas e gritos.

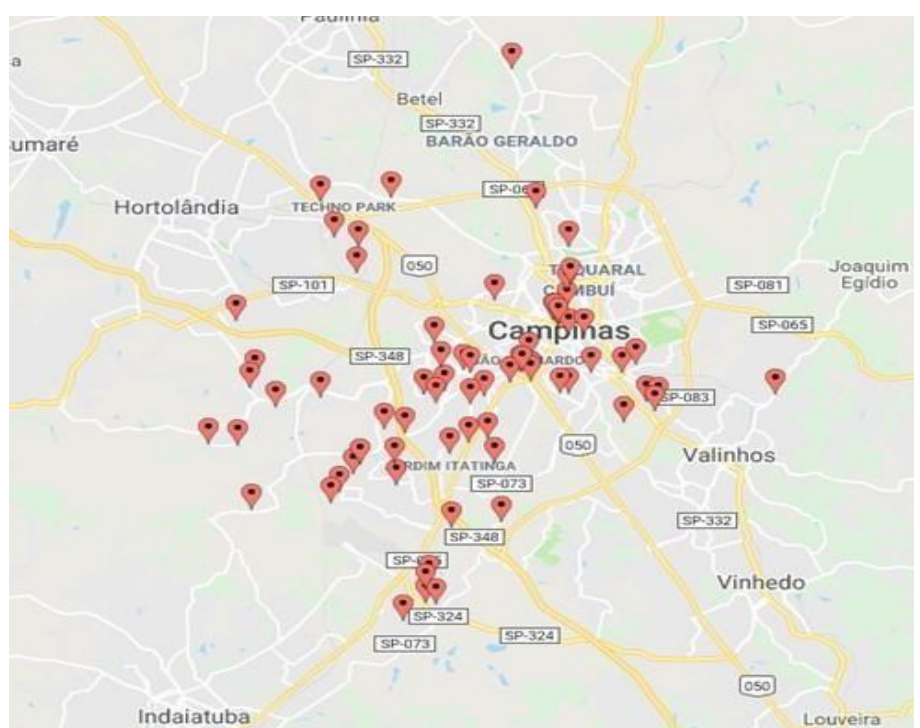

Figura 1. Locais de ocorrência dos atos infracionais registrados (Campinas, 2015-2018)

\section{Conclusões}

Apesar de existirem direcionamentos legais específicos às Juventudes, previstas pelo ECA, o procedimento dos policiais diante desta camada da população detém elementos que coincidem com os mesmos direcionados aos adultos. Deste modo, um dos maiores obstáculos para a concretização da Justiça Juvenil no Brasil é o próprio Estado e seu braço armado, o qual descumpre com o ECA ao exercer cotidianamente o genocídio da população jovem, negra de periferias.

\section{Agradecimentos}

Agradeço principalmente a minha parceira de pesquisa Luana Barbosa e meu orientador Frederico de Almeida. Também gostaria de agradecer aos meus amigues e familiares pelo apoio emocional e a CNPQ pelo apoio financeiro. 